\title{
Determining the Approaches of High School Students to Learning Physics
}

\author{
Gülbin ÖZKAN \& Gamze SEZGİN SELÇUK* \\ Dokuz Eylul University, Izmir, TURKEY
}

Received: 19.08 .2013

Accepted: 13.03 .2014

Abstract - The primary objective of this research was to adapt the Approaches to Learning Scale developed for the university level by Ellez \& Sezgin (2000) to a high school level physics (Approaches to Learning Physics Scale). The secondary objective was to use the adapted scale to examine the approaches of high school students to learning physics and explore how this variable changes according to gender and level of achievement in physics. The adapted scale was applied to a total of 329 high school students in the province of İzmir, Turkey for the purpose of testing the scale's validity and reliability. The reliability coefficient for the whole of the scale was found to be 0.86 . The data related to the secondary objective of the research were analyzed using frequencies, percentages, means, standard deviation, two-way multivariate analysis (two-way MANOVA), and follow-up tests. It was determined from the results of the analysis that the students' preference for both a deep and a surface approach to learning physics was slightly above average. It was found the students did not display a significant difference in their approaches to learning according to the gender variable but that there were significant differences between the students' approaches to learning according to the variable of achievement.

Keywords: approaches to learning, physics, high school students, gender, level of achievement

DOI No: 10.12973/nefmed.2014.8.1.a5

\begin{abstract}
Summary
\section{Introduction}

Defining the approaches of individuals in reaching high level and permanent products of learning in the learning process and organizing this process to enable deep learning are among the most important factors in learning.
\end{abstract}

\footnotetext{
* Corresponding author: Gamze SEZGiN SELÇUK, Assoc. Prof. Dr. in Physics Education, Buca Education Faculty, Dokuz Eylul University, Izmir, TURKEY.

E-mail: gamze.sezgin@deu.edu.tr
} 


\section{Purpose of the study}

The purpose of this study was to adapt the Approaches to Learning Scale developed by Ellez \& Sezgin (2000) to high school physics students and create an Approaches to Learning Physics Scale, determine high school students' preferred approaches to learning physics, and to find out whether students' approaches to learning display any significant differences according to the variables of gender and level of achievement. The study sought answers to the following sub-problems:

- Is the "Approaches to Learning Physics Scale" adapted for high school level a valid and reliable measurement instrument?

- What are the levels of preference that high school students display in their approaches to learning physics?

- Are there any significant differences between high school students' approaches to learning according to the interaction of gender and level of achievement?

\section{Methodology}

Since the research sought to determine the preference levels of high school students' approaches to learning physics and to evaluate these in terms of various variables (gender and achievement in physics), the descriptive method was used.

\section{Adaptation process}

In the adaptation process, the items in the Approaches to Learning Scale were first converted by the researchers into a form that would be suitable for a physics course, after which the new scale that was thus drawn up was given the name, "Approaches to Learning Physics Scale (ALPS)."

\section{Population and Sample}

The population of the study consisted of the students in the Anatolian High Schools in İzmir and the sample comprised the students of two different Anatolian High Schools in İzmir's district of Buca. To test the validity and reliability of the adapted scale, it was applied to a total of 329 high school students in the 9th, 11th and 12th grades.

\section{Data Analysis}

The Univariate ANOVA and the SPPS 15.0 program were used to analyze the data obtained from the ALPS in terms of frequency $(f)$, percentage $(\%)$, mean $(O)$, standard deviation $(S S)$, the two-way MANOVA, and the follow-up test for each dependent variable. 


\section{Results}

It was seen in the factor analysis that the items in the scale were clustered in three domains. These domains were named "deep approach 1," "surface approach," and "deep approach 2." The deep approach 1 domain consisted of 11, the surface approach of 11 and the deep approach 2 domain of 7 items. In addition, the Cronbach Alpha coefficients for the whole of the scale and its factors were calculated. The reliability coefficients for the subdomains of the scale were $0.84,0.82,0.74$, respectively, and the reliability coefficient for the whole scale was found to be 0.86 . The results show that the Approaches to Learning Physics Scale is a valid and reliable instrument. The data related to the secondary objective of the research were analyzed using frequencies, percentages, means, standard deviation, two-way multivariate analysis (two-way MANOVA), and follow-up tests. It was determined from the results of the analysis that the students' preferences for both a deep (in both sub-domains) and for a surface approach to learning physics were slightly above average. It was found that the students did not display a significant difference in their approaches to learning according to the gender variable but that there were significant differences between the students' approaches to learning (in the deep 1 and surface and deep 2 domains) according to the variable of achievement.

\section{Conclusion and Discussion}

A review of the students' mean scores on their approaches to learning (deep and surface) shows that their preference for any one of the approaches to learning was not very much greater than their preference for the other approach. This was an indication that the education offered in high school guided students toward both approaches.

High and average achievers were more likely to prefer the deep approach compared to low achievers. In the surface approach, the approach to learning scores of high achievers among the students were significantly less than the scores of the average or low achievers. Low scores in this domain meant that high achievers in high school preferred a surface approach to learning less than the other approach. This finding may be interpreted to mean that the higher a student's grades in physics, the more the deep approach to learning scores will display a tendency to rise. This is turn means that there is a positive relationship between achievement in physics and deep approaches to learning.

When the scale is reviewed as a whole and in terms of its sub-domains, the finding that the variable of gender does not appear to make a statistical difference makes it clear that 
female and male students at the secondary school level use the deep and surface approaches to learning in similar ways.

\section{Suggestions}

The level of students' preference in choosing a deep or surface approach to learning and the change in their approach according to (a) the topics in the course, (b) the teacher's method of teaching the course, (c) the student's gender, and (d) the student's achievement in the physics course should be examined through face-to-face in-depth interviews with students. Furthermore, face-to-face interviews with teachers could be used to verify the data collected from students. 


\title{
Lise Öğrencilerinin Fizik Öğrenme Yaklaşımlarının Belirlenmesi
}

\author{
Gülbin ÖZKAN ve Gamze SEZGİN SELÇUK ${ }^{\dagger}$ \\ Dokuz Eylül Üniversitesi, İzmir, TÜRKİYE
}

Makale Gönderme Tarihi: 19.08.2013

Makale Kabul Tarihi: 13.03 .2014

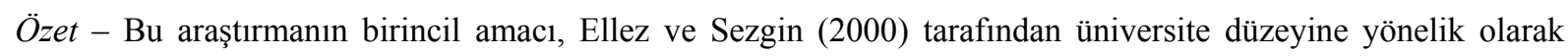
geliştirilen Öğrenme Yaklaşımları Ölçeği’nin lise düzeyinde fizik dersine uyarlamasını (Fizik Öğrenme Yaklaşımları Ölçeği) yapmaktır. Araştırmanın ikincil amacı, uyarlanan ölçek kullanılarak lise öğrencilerinin fizik öğrenme yaklaşımlarını ve bu değişkenin cinsiyet ve fizik başarısına göre değişimini incelenmektir. Uyarlaması yapılan ölçek, geçerlik-güvenirlik çalışmaları amacıyla İzmir ilinde lise düzeyinde öğrenim görmekte olan toplam 329 öğrenciye uygulanmıştır. Ölçeğin tümüne ait güvenirlik katsayı 0.86 olarak bulunmuştur. Araştırmanın ikincil amacı ile ilgili olan veriler frekans, yüzde, ortalama, standart sapma, iki yönlü çok değişkenli varyans analizi (two-way MANOVA) ve izleme testleri kullanılarak analiz edilmiştir. Elde edilen bulgular, öğrencilerin fizik dersinde hem derinsel hem de yüzeysel öğrenme yaklaşımlarını orta düzeyin biraz üzerinde tercih ettikleri belirlenmiştir. Cinsiyet değişkenine göre öğrencilerin öğrenme yaklaşımları arasında anlamlı bir fark olmadığı; bununla birlikte başarı değişkenine göre öğrencilerin öğrenme yaklaşımları arasında anlamlı farklılıklar olduğu saptanmıştır.

Anahtar Sözcükler: öğrenme yaklaşımları, fizik, lise öğrencileri, cinsiyet, başarı düzeyi

DOI No: 10.12973/nefmed.2014.8.1.a5

\section{Giriş}

Fizik, bilginin hızla yenilenerek üretildiği, değişime açık, günlük yaşamla iç içe gelişen bir bilimdir. Fizik eğitiminde, özellikle günümüzde gelişen teknolojiyle birlikte yaşam boyu öğrenmenin önemi anlaşılmış ve öğrencilerin öğrenmeyi nasıl gerçekleştirdiği konusuna odaklanılmıştır. Tüm bu gelişmeler ışığında fizik eğitiminde son yıllarda yapılan çalışmaların araştırma probleminin temelinde öğrencilerin fiziği nasıl öğrendikleri konusu yatmaktadır. $\mathrm{Bu}$ araştırmalar sonucunda (Ekinci, 2008; Kılıç ve Sağlam, 2007; Richardson, 1993; Sezgin Selçuk, Çalışkan ve Erol, 2007; Trigwell, Prosser ve Waterhouse, 1999; Öner, 2008)

\footnotetext{
† İletişim: Gamze SEZGiN SELÇUK, Doç. Dr., Fizik Eğitimi Anabilim Dalı, Buca Eğitim Fakültesi, Dokuz Eylül Üniversitesi, İzmir, TÜRKİYE.

E-mail: gamze.sezgin@deu.edu.tr
} 
öğrencilerin tümünün aynı öğrenme yaklaşımını benimsemediği, farklı öğrenme yollarını tercih ettiği kanısına varılmıştır.

Jackson (1994), öğrenme yaklaşımını, öğrenenin öğrenmeyi gerçekleştirmek için tercih ettiği stratejilerle ilişkilendirmiştir. Bu görüşüne dayalı olarak da, öğrenme ürünlerinin niteliğinin öğrenmek için seçilen yaklaşımın niteliği ile ilişkili olduğunu ileri sürmüştür. Ramsden (2003) öğrenme yaklaşımının tanımını, öğrenci ile onun gerçekleştirdiği öğrenme arasındaki ilişki olarak yapmıştır.

Öğrenme yaklaşımları konusundaki çalışmalara Marton ve Saljo (1976) öncülük etmiştir. Marton ve Saljo çalışmalarında öğrencilere dağıtılan akademik bir makalenin okunmasını istemişler ve makalenin konusunu öğrencilerin nasıl ele aldıklarını araştırmışlardır. Deneysel nitelikli bu çalışmalarında, öğrencilerin makaleyi okuduktan sonra neler öğrenmiş olduklarını, makaleyi okuma işine nasıl yaklaştıklarını, makaleyi okumaları sırasındaki davranışlarını belirlemek amacıyla öğrencilerle görüşmeler yapılmışlardır. Çalışmada öğrencilerin bazıları okudukları makaleyi, sorulması beklenen sorulara cevap verebilmeleri için ezberlenmesi gereken ayrı bilgi ünitelerinin toplamı olarak görmüşlerdir. Diğer öğrenciler ise metni bir bütün olarak görerek, yazarın görüşünü yakalamaya ve makalenin ardında yatan anlamı kavramaya çalışmışlardır. Araştırmalarının sonucunda öğrencilerin öğrenmeyi ele alış biçimlerinin altında yatan sebeplerin öğrencilerin öğrenmeye olan yaklaşımlarının olduğunu belirlemişlerdir. Bu yaklaşımları yüzeysel ve derinsel öğrenme yaklaşımları olarak nitelendirmişlerdir.

Marton ve Saljo'nun çalışmalarından sonra, İngiltere ve Avustralya'da başka araştırmalar da yapılmıştır. Bu araştırmalar sonucunda da Marton ve Saljo'nun bulgularını destekleyici sonuçlar ortaya konulmuştur (Shale ve Trigwell, 2004; aktaran, Ekinci, 2008). Ayrıca Ramsden (1979) tarafindan derinsel ve yüzeysel öğrenme yaklaşımlarına ek olarak "stratejik yaklaşım” olarak adlandırdığı üçüncü bir yaklaşım ortaya konulmuştur. Bu yaklaşıma sahip öğrencilerin, öncelikli amacının en yüksek notu almak olduğu; bu yüzden de yerine göre hem derinsel hem de yüzeysel öğrenme yaklaşımlarını kullandıkları, yarışmacı ve mesleksel güdüye sahip oldukları belirlenmiştir. Bu yaklaşım öğrenme yaklaşımından daha çok çalışma yaklaşımı olarak düşünüldüğü için (örn., Morgan, 1993), bu çalışmada stratejik yaklaşıma yer verilmemiştir.

Öğrenme yaklaşımları konusunda yapılan ilk çalışmaların çoğu nitel yöntemlerle gerçekleştirilmiştir. Byrne, Flood ve Willis (1999) öğrenci sayısının çokluğu göz önüne alınacak olursa sağlıklı birebir görüşmelerin yapıldığını düşünmenin pek de gerçekçi 
sayılamayacağını belirtmişlerdir. Richardson (1993), nitel yöntemlerin yerine standart anketleri kullanarak öğrenme yaklaşımlarını belirlemenin daha güvenilir olacağını önermiştir.

Kalıcı ve üst düzey öğrenme ürünlerine ulaşmada bireylerin öğrenme yaklaşımlarını belirlemek ve öğrenme sürecini derinsel öğrenmeler oluşturacak şekilde düzenlemek öğrenme sürecinin en önemli faktörlerinden biridir. Derinsel Öğrenme Yaklaşımı, karşılaşılan bilginin gerçekliğini sorgulamayı ayrıca ön bilgi ve deneyimle yeni bilgiyi bütünleştirme girişimini içermektedir (Weinstein ve Mayer, 1986). Yüzeysel Öğrenme Yaklaşımı ise, bilginin tekrarlanması ve ezberlenmesini içermektedir (Entwistle ve Ramsden, 1983). Derinsel öğrenme yaklaşımı yapılandırmacı yaklaşımı benimserken, yüzeysel öğrenme yaklaşımı geleneksel öğretim modelini benimser (Dart, Burnett ve Purdie, 2000). Byrne, Flood ve Willis (2002), derinsel öğrenme yaklaşımını benimseyen öğrencilerin yüksek akademik başarılara sahip olduğunu buna karşın yüzeysel öğrenme yaklaşımını benimseyen öğrencilerin ise daha düşük başarılara sahip olduklarını belirtmişlerdir.

Derinsel yaklaşımla öğrenen öğrenciler, daha mikroskobik konularda ve özel bir hazırlık gerekmeksizin açık ve net açıklamalar yapabilirlerken, yüzeysel öğrenen öğrenciler soruyu sadece gördükleri kadarıyla yetinerek herhangi bir makroskobik boyuta ya da bir mekanizmaya bağlı olarak açıklamakta yetersiz kalmaktadırlar (Chin ve Brown, 2000). Bazı öğrenciler derinsel öğrenme yaklaşımına daha fazla eğilim gösterirken bazı öğrenciler ise yüzeysel öğrenme yaklaşımına daha fazla eğilimlidir. Öğrencilerin bu eğilimleri kişisel özelliklerine göre de değişebilmektedir (Biggs, 1999).

Bazı araştırmalar öğrencilerin öğrenme yaklaşımı seçimlerini öğrenme ortamı ile ilgili algılarının etkilediğine yönelik bulgular sunmaktadır (örn., Mayya, Rao ve Ramnarayan, 2004; Trigwell, Prosser ve Waterhouse, 1999). Ramsden ve Entwistle (1981) sinifta uygulanan öğretim yöntemleri, öğretmenin coşkusu, öğretilen bilginin düzeyi ve ilerleme hızı gibi öğretimsel özelliklerin öğrencilerin öğrenme yaklaşımları üzerinde önemli etkiye sahip olduğunu belirtmişlerdir.

Farklı öğrenme yaklaşımlarını benimseyen öğrencilerde gözlenen öğrenme ürünlerinden bazıları ise sırasıyla şöyledir (Hua, Williams ve Hoi, 2001):

Derinsel yaklaşım

- Bilginin uzun süreli olarak hatırda tutulabilmesi,

- Bilgiyi yeni durumlara uyarlayabilme,

- Yeni anlamlar ve yeni fikirler üretebilme,

- Bağımsız bir öğrenen olma. 
Yüzeysel yaklaşım

- Kuramsal bilginin sınırlı düzeyde anlaşılması,

- Mantıksal bir tartışma geliştirmede zorluk çekme,

- Anahtar fikirleri fark edememe,

- Örnekler ve ilkeleri birbirinden ayırt edememe,

- Öğrenilenlerin çok çabuk unutulması.

Alan yazın incelendiğinde ülkemizde öğrenme yaklaşımları ile ilgili yapılan çalışmaların özellikle son yıllarda artmaya başladığı görülmüştür (Berberoğlu ve Hei, 2003; Çalışkan, Sezgin-Selçuk ve Erol, 2006; Ekinci, 2008; Ellez ve Sezgin, 2002; Kızılgüneş, 2007; Öner, 2008; Tural-Dinçer ve Akdeniz, 2008; Ünal-Çoban ve Ergin, 2006; Yıldız, 2008). Yurt dışında bu konuda yapılan çalışmaların sayısı oldukça fazla olmakla beraber; fizik eğitiminde doğrudan öğrenme yaklaşımlarının incelendiği çok az araştırmaya rastlanmıştır (Dickie, 2003; Nguyen, 1998; Prosser ve Millar, 1989; Prosser, Walker ve Millar, 1996). Baz1 araştırmalarda ise öğrenme yaklaşımlarının sadece strateji boyutunun ele alındığ 1 belirlenmiştir (Austin ve Shore, 1995; Bruce, 2001; Harper, Etkina ve Lin, 2003; Guimberteau, 1992; Johnston, 1994; Koch, 2001; Koch ve Eckstein, 1991; Rouet, VidalAbarca, Erboul ve Millogo, 2001; Sezgin Selçuk, Sahin ve Açıkgöz, 2011; Vertenten, 2002; Zieneddine ve Abd- El-Khalick, 2001).

Öğrenme yaklaşımı ile ilgili yapılan çalışmaların sayısının oldukça fazla olmasıyla beraber alan bazında (fen eğitimi) bakıldığında bu çalışmaların sayısı oldukça azdır. Örneğin, Ünal-Çoban ve Ergin (2006) buluş yoluyla yapılandırılmış sınıf-içi etkinliklerin ilköğretim 7. sınıf öğrencilerinin feni öğrenme yaklaşımları üzerindeki etkisini araştırmış ve geleneksel yöntemle karşılaştırmışlardır. Araştırma bulgularına bakıldığında buluş yoluyla öğrenme ve geleneksel yöntemin öğrenme yaklaşımları üzerindeki etkileri arasında anlamlı bir farklılık bulunmamıştır. Ünal-Çoban ve Ergin (2008) bir diğer çalışmalarında ilköğretim çağındaki öğrencilerin fen dersine yönelik öğrenme yaklaşımlarını belirlemişlerdir. Sonuçta öğrencilerin hem derinlemesine hem de yüzeysel öğrenme yaklaşımlarına sahip oldukları görülmüştür. Öğrencilerin feni öğrenme yaklaşımlarını inceleyen bir diğer çalışma da Aydoğdu (2009) tarafından yapılmıştır. Bu çalışmada fen ve teknoloji dersinde kullanılan araştırmaya dayalı ve açık uçlu deney tekniklerinin öğrencilerin feni öğrenme yaklaşımlarına etkisi incelenmiştir. Deney 1 grubunda açık uçlu deney tekniği, deney 2 grubunda araştırmaya dayalı deney tekniği ve kontrol grubunda fen ve teknoloji öğretim programı uygulanmıştır. Araştırma 
sonucunda öğrencilerin feni öğrenme yaklaşımlarının açısından deney 1 ve deney 2 grubu lehine anlamlı bir farklılık bulunmuştur.

Aycan ve Yumuşak (2003) lise düzeyinde öğrenciler ile yaptıkları çalışmalarında öğrencilerin genellikle, fizik konularının soyut kavramlar içermesinden ve öğrenmeden ezberleme yoluna gittiklerinden şikâyet ettiklerini rapor etmektedirler. Ramsden (2000) yüzeysel yaklaşımı tercih eden öğrencilerin yalnızca görevin gerektirdiklerini karşılama niyetinde olduklarını, bilgiyi ezberlemekte, ilkeleri örneklerden ayırmada başarısız olduklarını ve görevi dışsal bir zorlama olarak gördüklerini ifade etmektedir. Bu bağlamda, bilgilerin öğrenciler tarafından öğrenilmesinin zorlaştığını ve öğrencilerin fizik dersine karşı ilgilerinin de azaldığını söylenebilir.

2007 Ortaöğretim Fizik Programında olduğu gibi 2013 Yeni Fizik Dersi Öğretim Programı'nda yaşam temelli yaklaşım (real life context-based) esas alınmıştır. M.E.B. Talim ve Terbiye Kurulu Başkanlığg (2013) tarafından güncellenen yeni ortaöğretim fizik programında öğrenciler arasındaki bireysel farklılıkların dikkate alınması, öğrenciyi aktif hale getirip, bilgiyi kendilerinin yapılandırması, anlamlı bir öğrenmenin gerçekleşebilmesi için öğrenmeye ilişkin birçok kuram, yaklaşım ve yöntemin ortak paydası olan bilişsel ve duyuşsal ilkelerin benimsenmesi amaçlamıştır. Programda öğrencilere kazandırılması hedeflenen kazanımlar, öğrencilerin bilimsel süreç becerileri çerçevesinde analitik ve eleştirel düşünme becerilerinin gelişmesine, fizik bilgisini günlük yaşam içinde kullanmasına, bilimi, teknoloji, toplum ve çevre ile ilişkilendirmesine yönelik olarak hazırlanmıştır.

$\mathrm{Bu}$ araştırmada ülkemizde lise düzeyinde öğrenim görmekte olan öğrencilerin fizik dersini öğrenirken tercih ettikleri öğrenme yaklaşımlarının güvenilir bir ölçme aracı ile belirlenmesi sayesinde halihazırda uygulanmakta olan fizik öğretim programları ve derslerde kullanılan öğretim yöntemlerinin de gözden geçirilmesine ve geliştirilmesine katkı sağlayacağı düşünülmektedir. Ayrıca alan yazında, ilköğretim düzeyinde fen bilimleri dersinin fizikle ilgili bazı konularında (elektrik, kuvvet ve hareket basınç) öğrenme yaklaşımları üzerine yapılan çalışmalara rastlanmasına rağmen lise düzeyinde bir çalışmaya rastlanmamıştır. Bu durum da bu çalışmanın önemini arttırmaktadır.

\section{Araştırmanın Amacı}

Bu araştırmada Ellez ve Sezgin (2000) tarafından geliştirilen Öğrenme Yaklaşımları Ölçeği’ni lise düzeyinde fizik dersine uyarlamak (Fizik Öğrenme Yaklaşımları Ölçeği); lise öğrencilerinin fizik öğrenme yaklaşımlarını tercih düzeylerini belirlemek, öğrencilerin öğrenme yaklaşımlarının cinsiyet ve başarı düzeyi değişkenlerine göre anlamlı bir farklılık 
gösterip göstermediğini bulmak amaçlanmıştır. Bu araştırmada aşağıdaki alt problemlere yanıt aranmıştır:

- Lise düzeyinde fizik dersine uyarlanan Fizik Öğrenme Yaklaşımları Ölçeği geçerli ve güvenilir bir ölçme aracı mıdır?

- Lise öğrencilerinin fiziği öğrenme yaklaşımlarını tercih etme düzeyleri nasıldır?

- Cinsiyet ve başarı düzeyinin ortak etkisine göre lise öğrencilerinin öğrenme yaklaşımları arasında anlamlı farklılıklar var mıdır?

\section{Yöntem}

$\mathrm{Bu}$ araştırma ile lise öğrencilerinin fizik öğrenme yaklaşımlarını tercih etme düzeylerinin belirlenmesi ve bazı değişkenler (cinsiyet ve fizik başarısı) bakımından değerlendirilmesi amaçlandığından betimsel yöntem kullanılmıştır.

\section{Uyarlama Çalışması}

$\mathrm{Bu}$ araştırmada lise öğrencilerinin fizik dersini öğrenmeye yönelik yaklaşımları Ellez ve Sezgin (2000) tarafından üniversite düzeyine yönelik olarak geliştirilen ve genel olarak her derse uyarlanabilecek bir yapıda olan 30 maddelik “Öğrenme Yaklaşımları Ölçeği (ÖYÖ)'nin lise düzeyinde fizik dersine uyarlaması yapılarak incelenmiştir. ÖYÖ’nde yer alan maddeler "Kesinlikle Katılıyorum", "Katılıyorum”, “Kararsızım”, "Katılmıyorum”, “Kesinlikle Katılmıyorum" şeklinde belirtilen 5'li dereceleme ölçeğinde düzenlenmiştir. Ölçekteki maddeler "Kesinlikle Katılıyorum” seçeneğinden başlamak üzere 5, 4, 3, 2, 1 şeklinde puanlanmaktadır. Faktör analizi sonuçlarına göre, bu ölçekte yer alan maddeler iki boyutta toplanmış olup; bu boyutlar "derinsel yaklaşım” ve "yüzeysel yaklaşım” olarak adlandırılmıştır. Derinsel yaklaşım boyutunda 19, yüzeysel yaklaşım boyutunda ise 11 madde yer almaktadır. Ölçeğe ait Cronbach Alpha güvenirlik katsayısı 0.81; derinsel ve yüzeysel yaklaşım alt boyutlarına ait güvenirlik katsayıları sırasıyla 0.82 ve 0.76 dır.

Ölçek uyarlama sürecinde Öğrenme Yaklaşımları Ölçeği’nde yer alan maddeler önce araştırmacılar tarafından fizik dersine uyabilecek bir forma dönüştürülmüş ve yeni oluşturulan bu ölçeğe "Fizik Öğrenme Yaklaşımları Ölçeği (FÖYÖ)" adı verilmiştir. Daha sonra, elde edilen bu form fizik eğitiminde uzman 2 öğretim üyesi, program geliştirmede uzman 1 öğretim üyesi ve 2 lise fizik öğretmenin görüşlerine sunulmuştur. Uzmanların önerileri doğrultusunda yeniden düzenlenen FÖYÖ İzmir ilinde bulunan bir Anadolu lisesinde öğrenim gören 50 öğrenciye pilot uygulama şeklinde uygulanmış ve öğrencilerden gelen 
geribildirimler doğrultusunda düzenlenerek geçerlik-güvenirlik çalışmasının yürütüleceği çalışma grubuna uygulanacak şekle getirilmiştir.

\section{Evren ve Örneklem}

$\mathrm{Bu}$ çalışmanın evrenini İzmir ilinde bulunan Anadolu Lisesi öğrencileri, örneklemini ise İzmir ili Buca İlçesinde bulunmakta olan iki farklı Anadolu Lisesinin öğrencileri oluşturmaktadır. Uyarlama çalışması yapılan ölçek, geçerlik-güvenirlik çalışmaları amacıyla 9., 11. ve 12. sınıf düzeylerinde öğrenim görmekte olan toplam 329 öğrenciye uygulanmıştır. Bu öğrenciler Ortaöğretim 11. sınıf Fizik Programı'nın dayalı olduğu yaşam temelli öğrenme yaklaşımı ile ders işlememektedir. Çalışmanın örneklemini oluşturan öğrencilerin derslerine giren 3 farklı Fizik öğretmeniyle görüşülmüş, üç öğretmen de konuları yetiştirmenin çok zor olduğu gerekçesiyle programı uygulamadıklarını belirtmişlerdir. Veriler 2011-2012 akademik yılının bahar döneminde toplanmıştır. Ölçeğin tamamını yanıtlayan öğrenci sayısı 329 olduğu için; bu öğrencilerden elde edilen veriler değerlendirmeye alınmıştır. Öğrencilerin yaşları 15 ile 17 arasında değişmiştir. Araştırmada öğrencilerin başarı durumları (düşük, orta ve yükssek başarı) 2011-2012 akademik yılının güz dönemine ait fizik karne notuna göre belirlenmiştir. Başarı düzeylerini belirlemede kullanılan puan aralıkları 100'lük not sistemine göre sırasıyla şöyledir: Düşük (0-44), Orta (45-69) ve Yüksek (70-100). Öğrencilerin cinsiyet ve başarı düzeyi değişkenlerine göre dağılımları Tablo 1'de verilmiştir. Kız ve erkek öğrencilerin başarı düzeylerine göre dağılımları arasında fark olup olmadığı ki-kare testi ile analiz edilmiş ve anlamlı bir fark saptanmamıştır $\left[\chi^{2}{ }_{(2)}=0.445 \mathrm{p}>0.05\right]$.

Tablo 1 Öğrencilerin Cinsiyet ve Başarı Düzeyi Değişkenlerine Göre Dağılımları

\begin{tabular}{lcccc}
\hline \multicolumn{1}{c}{ Cinsiyet } & \multicolumn{3}{c}{ Başarı } & Toplam \\
\hline Kız & Düsük & Orta & Yüksek & \\
Erkek & 42 & 81 & 49 & $172(\% 52,3)$ \\
Toplam & 37 & 70 & 50 & $157(\% 47,7)$ \\
& $79(\% 24)$ & $151(\% 45,9)$ & $99(\% 30,1)$ & 329 \\
\hline
\end{tabular}

Not: Parantez içindeki veriler öğrencilerin ait olduğu gruba ilişkin yüzdelik dağı lımlarını göstermektedir.

\section{Verilerin Analizi}

Çalışma grubundan toplanan verilerin analizinde SPSS 15.0 paket programı kullanılmıştır. Ölçeğin lise düzeyinde fizik dersine uyarlanması sürecinde faktör yapısının belirlenmesi amacıyla verilere açımlayıcı faktör analizi uygulanmıştır. Ölçeğin ve alt ölçeklerin güvenirliğine ilişkin Cronbach Alfa güvenirlik katsayıları hesaplanmıştır. Araştırmanın bağımsız değişkenleri cinsiyet ve fizik başarısı; bağımlı değişkenleri fizik 
öğrenme yaklaşımları puanlarıdır (derinsel yaklaşım 1, yüzeysel yaklaşım, derinsel yaklaşım 2). FÖYÖ’den elde edilen veriler frekans $(f)$, yüzde $(\%)$, ortalama $(O)$, standart sapma $(S S)$ ve iki yönlü çok değişkenli varyans analizi (two-way MANOVA) ve izleme testi olarak her bir bağımlı değişken için Varyans Analizi (univariate ANOVA) kullanılarak, SPPS 15.0 programında analiz edilmiştir. Her bir bağımsız değişkenin bağımlı değişkenler üzerindeki etkilerini incelemeden önce, MANOVA'nın varsayımları test edilmiştir. Bağımlı değişkenlere ilişkin puanların tek değişkenli ve çok değişkenli normal dağılım gösterdiği; varyanskovaryans matrislerinin homojenliği ise Box'1n M testi ( $p>0.05)$ kullanılarak belirlenmiştir. Her bir bağımlı değişken için varyansların homojen olup olmadığına Levene testi ile bakılmıştır. Derinsel 1 ve Yüzeysel alt boyutları için varyansların homojen olduğu $(p=0.641$; $\mathrm{p}=0.260)$, derinsel 2 alt boyutu için ise homojen olmadığ $1(p<0.05)$ belirlenmiştir. ANOVA sonuçlarının anlamlı çıkması durumunda, farklılığın hangi gruplardan kaynaklandığını belirlemek amacıyla, post-hoc çoklu karşılaştırma testlerinden Bonferroni (varyansların eşit olduğu durumlar için) ve Tamhane T2 testi (varyansların eşit olmadığı durumlar için) kullanılmıştır. Verilerin analizi 0.05 önem düzeyinde gerçekleştirilmiştir.

\section{Bulgular}

\section{Ölçeğe İlişkin Geçerlik-Güvenirlik Çalışmaları}

FÖYÖ’nin geçerlilik çalışmaları doğrultusunda, ölçeğin kapsam geçerliği ve yapı geçerliği incelenmiştir. Benzer nitelikte bir ölçeğe ulaşılamadığg için benzer ölçekler geçerliği incelenememiştir. Kapsam geçerliği için bu makalenin "Uyarlama Çalışması” bölümünde de belirtildiği gibi uzman görüşlerine (Kaplan \& Saccuzzo, 2005) başvurulmuştur. Ölçeğin yap1 geçerliliğini test etmek amacıyla çalışma grubundan elde edilen verilere Kaiser-Meyer-Olkin (KMO) değeri ve Barlett Küresellik Testi uygulanmıştır. KMO değeri 0.839 olarak hesaplanmıştır. Buna ek olarak, Barlett küresellik testi anlamlı bulunmuştur $\left[X^{2}=1842.215\right.$, $\mathrm{p}<0.001]$. Verilerin faktör analizine uygunluğu için KMO değerinin 0.60 'dan yüksek ve Barlett testinin anlamlı çıkması verilerin faktör analizi için uygun olduğunu göstermektedir (Büyüköztürk, 2011).

Ölçek lise düzeyinde fizik dersine uyarlandığı için, ölçeğin uygulandığı öğrenci grubundan toplanan veriler üzerinden nasıl bir faktör yapısı gösterdiğini incelemek amacıyla verilere Açımlayıcı Faktör Analizi (Exploratory Factor Analysis) uygulanmıştır. Verilere Varimax dik döndürme tekniği (Büyüköztürk, 2011) kullanılarak temel bileşenler analizi (Principle component analysis) uygulanmıştır. İlk analiz sonuçları incelendiğinde, ölçeğin 
özdeğeri (eigen value) birden büyük 7 faktörde toplandığı görülmüştür. Açımlayıcı faktör analizi ile ortaya çıkan faktörlerin özdeğerlerinin gösterildiği grafikte (Bkz. Şekil 1) hızlı düşüşlerin olduğu üç önemli faktör vardır. Yapılan son analizde faktör sayısı maddelerin içeriklerine bakıldığında kavramsal olarak uygun olabileceği düşünülen üç faktör ile sınırlandırılmıştır. Analiz sonucunda faktör yükü 0.40 'in altında olan bir madde (6 no'lu) ölçekten çıkartılmış ve ölçekteki madde sayısı 29'a inmiştir.

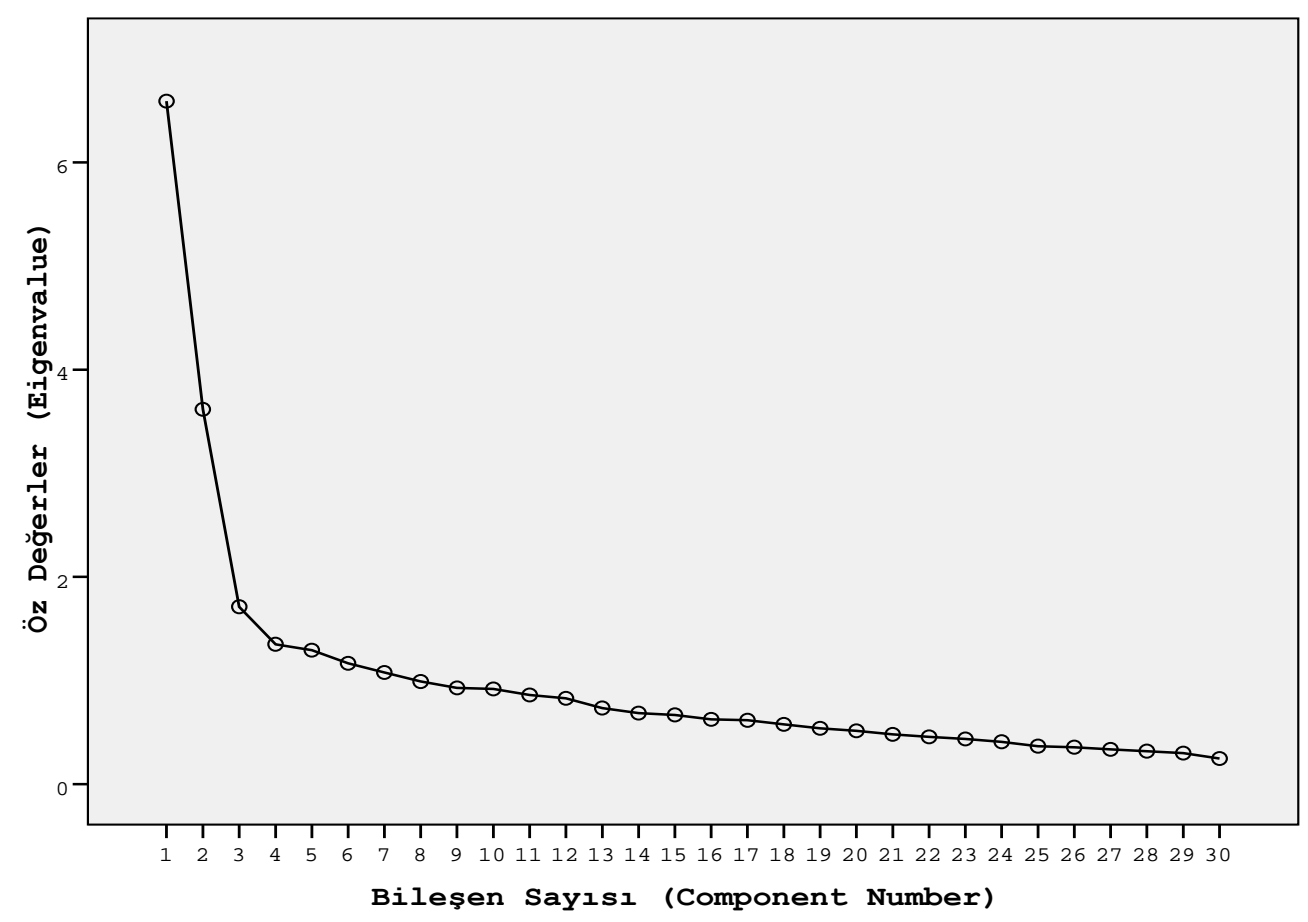

Şekil 1 Açımlayıcı Faktör Analizi Özdeğer Grafiği (Scree Plot)

Ölçeğe ait düzeltilmiş toplam madde- ölçek korelasyonları Tablo 2'de verilmiştir.

Tablo 2 Ölçek için Düzeltilmiş Toplam Madde-Ölçek Korelasyonları

\begin{tabular}{ll|ll}
\hline Madde & $\begin{array}{l}\text { Düzeltilmiş } \\
\text { toplam } \\
\text { madde-ölçek } \\
\text { korelasyonları }\end{array}$ & Madde & $\begin{array}{l}\text { Düzeltilmiş } \\
\text { toplam } \\
\text { madde-ölçek } \\
\text { korelasyonları }\end{array}$ \\
\hline $\mathrm{m} 1$ & .537 & $\mathrm{~m} 16$ & .339 \\
\hline $\mathrm{m} 2$ & .379 & $\mathrm{~m} 17$ & .410 \\
\hline $\mathrm{m} 3$ & .492 & $\mathrm{~m} 18$ & .290 \\
\hline $\mathrm{m} 4$ & .390 & $\mathrm{~m} 19$ & .337 \\
\hline $\mathrm{m} 5$ & .359 & $\mathrm{~m} 20$ & .491 \\
\hline $\mathrm{m} 6$ & .495 & $\mathrm{~m} 21$ & .426 \\
\hline $\mathrm{m} 7$ & .361 & $\mathrm{~m} 22$ & .296 \\
\hline
\end{tabular}




\begin{tabular}{ll|ll}
\hline $\mathrm{m} 8$ & .311 & $\mathrm{~m} 23$ & .285 \\
\hline $\mathrm{m} 9$ & .444 & $\mathrm{~m} 24$ & .367 \\
\hline $\mathrm{m} 10$ & .403 & $\mathrm{~m} 25$ & .285 \\
\hline $\mathrm{m} 11$ & .402 & $\mathrm{~m} 26$ & .323 \\
\hline $\mathrm{m} 12$ & .453 & $\mathrm{~m} 27$ & .462 \\
\hline $\mathrm{m} 13$ & .383 & $\mathrm{~m} 28$ & .530 \\
\hline $\mathrm{m} 14$ & .503 & $\mathrm{~m} 29$ & .439 \\
\cline { 1 - 2 } $\mathrm{m} 15$ & .346 & \multicolumn{2}{l}{}
\end{tabular}

Maddeler kavramsal olarak incelendiğinde "Derinsel Öğrenme" yaklaşımına uyan maddelerin iki ayrı faktörde, "Yüzeysel Öğrenme" yaklaşımına uyan maddelerin ise tek faktörde toplandığı görülmüştür. Bu faktörler sırasıyla "Derinsel yaklaşım 1", "Yüzeysel yaklaşım" ve "Derinsel yaklaşım 2" olarak isimlendirilmiştir. "Derinsel yaklaşım 1" boyutunda 11 madde $(12,21,11,3,10,13,22,25,29,7,28$ no lu), "Yüzeysel yaklaşım" boyutunda 11 madde $(8,24,14,4,16,18,27,26,17,20,19$ no lu) ve "Derinsel yaklaşım 2" boyutunda ise 7 madde $(9,30,1,23,2,15,5$ no lu) yer almaktadır. Bu faktörler için özdeğerler sırasıyla şöyle belirlenmiştir: 6.591, 3.617, 1.712. Derinsel yaklaşım 1 faktörü toplam varyansın \%14.93 ünü, yüzeysel yaklaşım faktörü \%13.67 sini; Derinsel yaklaşım 2 faktörü \%11.14 ünü; üç faktör ise birlikte toplam varyansın \%40'ını açıklamaktadır.

Tablo 3'de faktörlere ilişkin tanımlamalara ve örnek ölçek maddelerine yer verilmiştir.

Tablo 3 Alt Ölçek Tanımları ve Örnek Maddeler

\begin{tabular}{|c|c|c|}
\hline Alt Ölçekler & Tanımları & Örnek Maddeler \\
\hline $\begin{array}{l}\text { Derinsel yaklaşım } 1 \\
\text { (aktiflik-planlılı) }\end{array}$ & $\begin{array}{l}\text { Araştırma ve etkinlikler } \\
\text { yapmak isteme, bilgiyi } \\
\text { keşfetme, hedefler } \\
\text { koyma ve planlı çalışma }\end{array}$ & $\begin{array}{l}\text { "Fizik dersinde araştırma konuları } \\
\text { verilsin isterim."(m11) } \\
\text { "Boş zamanlarımda fizikle ilgili } \\
\text { faaliyetlerle (deney, gözlem, } \\
\text { araştırma yapma vb.) uğraşmak } \\
\text { hoşuma gider."(m20) } \\
\text { "Fizik dersinde öğrendiklerimle } \\
\text { günlük yaşam arasında bağ kurmaya } \\
\text { calışırım."(m28) }\end{array}$ \\
\hline $\begin{array}{l}\text { Yüzeysel yaklaşım } \\
\text { (isteksizlik-pasiflik- } \\
\text { yüzeysel öğrenme) }\end{array}$ & $\begin{array}{l}\text { Dersle ilgili bir şeyler } \\
\text { yapmaya üşenme, } \\
\text { dersten soğuma, pasif } \\
\text { kalma, } \\
\text { ilgilenmeme, dersle } \\
\text { sadece sınav zamanı } \\
\text { çalışma, zayır not } \\
\text { almayacak radar } \\
\text { calısma, kolay soruların }\end{array}$ & $\begin{array}{l}\text { "Fizik dersini çalışırken ezberlemeyi } \\
\text { tercih ederim."(m23) } \\
\text { "Fizik dersinde anlatılanlarla } \\
\text { ilgilenmem."(m25) } \\
\text { "Fizik derslerine sadece sınav } \\
\text { zamanı geldiğinde çalışırım." (m15) } \\
\text { "Fizik dersinden zayı not } \\
\text { almayacak kadar çalışırım."(m18) }\end{array}$ \\
\hline
\end{tabular}




\begin{tabular}{|c|c|c|}
\hline & $\begin{array}{lr}\text { sorulmasın1 } & \text { isteme, } \\
\text { ayrıntıları } & \text { ögrenmek } \\
\text { istememe } & \end{array}$ & \\
\hline $\begin{array}{l}\text { Derinsel yaklaşım } 2 \\
\text { (irdeleme) }\end{array}$ & $\begin{array}{l}\text { Derinlemesine } \\
\text { sahibi olmak isteme, } \\
\text { anlaşılmayan bir yer } \\
\text { kalmasını istememe, } \\
\text { başkalarından yardım } \\
\text { isteme }\end{array}$ & $\begin{array}{l}\text { "Fizik dersi sırasında } \\
\text { açıklig kig konu } \\
\text { rahatsız eder."(m29) } \\
\text { "Fizik dersinde sunulan bilgileri } \\
\text { farklı kaynaklardan araştırarak } \\
\text { öğrenirim." (m2) }\end{array}$ \\
\hline
\end{tabular}

Ölçeğe ilişkin açımlayıcı faktör analizi sonuçları Tablo 4'de verilmiştir.

Tablo 4 Açımlayıcı Faktör Analizine Göre Fizik Öğrenme Yaklaşımları Ölçeği Alt Faktörleri ve Maddelere Göre Faktör Yükleri

\begin{tabular}{|c|c|c|c|}
\hline Madde No & Derinsel 1 & Yüzeysel & Derinsel 2 \\
\hline 12 & .769 & & \\
\hline 21 & .728 & & \\
\hline 11 & .654 & & \\
\hline 3 & .585 & & \\
\hline 10 & .571 & & \\
\hline 13 & .562 & & \\
\hline 22 & .522 & & \\
\hline 25 & .508 & & \\
\hline 29 & .497 & & \\
\hline 7 & .460 & & \\
\hline 28 & .424 & & \\
\hline 8 & & .689 & \\
\hline 24 & & 643 & \\
\hline 4 & & .628 & \\
\hline 14 & & 608 & \\
\hline 16 & & .602 & \\
\hline 18 & & .590 & \\
\hline 27 & & .584 & \\
\hline 26 & & .583 & \\
\hline 17 & & .547 & \\
\hline 20 & & .512 & \\
\hline 19 & & .489 & \\
\hline 9 & & & .719 \\
\hline 30 & & & .616 \\
\hline 1 & & & .597 \\
\hline 23 & & & .567 \\
\hline 2 & & & .501 \\
\hline 15 & & & .494 \\
\hline 5 & & & .422 \\
\hline Özdeğerler & 6.591 & 3.617 & 1.712 \\
\hline Açık. Var. $(\%)$ & 22 & 12 & 6 \\
\hline
\end{tabular}

Tablo 4' de görüldüğü gibi birinci faktördeki madde faktör yükleri 0.424-0.769, ikinci faktörde 0.489-0.68 ve üçüncü faktörde 0.422-0.719 arasında değişmiştir. Ölçeğin tamamında ise madde faktör yüklerinin 0.422-0.769 arasında değiştiği gözlenmiştir. 
Yap1 geçerliğinden sonra, FÖYÖ’nin güvenilirlik çalışmaları kapsamında iç tutarlılığını belirlemek amacıyla Cronbach Alfa katsayısına bakılmıştır. Tüm ölçeğin güvenirlik katsayısı 0.865 olup; alt ölçeklere ait güvenirlik katsayıları derinsel 1, yüzeysel ve derinsel 2 için sırasıyla $0.845,0.820$ ve 0.743 olarak bulunmuştur.

\section{Öğrencilerin Fizik Öğrenme Yaklaşımlarını Tercih Etme Düzeyleri}

Lise düzeyinde öğrenim gören öğrencilerin fiziği öğrenme yaklaşımlarını tercih etme düzeylerinin belirlenmesi amacıyla Fizik Öğrenme Yaklaşımları Ölçeği’nin alt boyutlarından aldıkları puanların ortalamaları ve standart sapmaları hesaplanmıştır (Tablo 5).

Tablo 5 Fizik Öğrenme Yaklaşımları Ölçeği’nin Alt Boyutlarına Ait Betimsel İstatistikler

\begin{tabular}{lccc}
\hline Alt Boyutlar & N & O & SS \\
\hline Derinsel 1 & 329 & 34,79 & 8,09 \\
Yüzeysel & 329 & 35,12 & 7,98 \\
Derinsel 2 & 329 & 25,44 & 4,65 \\
\hline
\end{tabular}

Betimsel bulguların sunulmasında ve değerlendirilmesinde ölçeğin alt boyutlarından alınabilecek minimum, orta ve maksimum puanları gösteren Tablo 6 ölçüt olarak kullanılmıştır.

Tablo 6 Fizik Öğrenme Yaklaşımları Ölçeği'nin Alt Boyutlarına Ait Puanlama Ölçütü

\begin{tabular}{lccc}
\hline Alt Boyutlar & Minimum Puan & Orta Puan & Maksimum Puan \\
\hline Derinsel 1 & $11 \times 1,00=11,00$ & $11 \times 3,00=33,00$ & $11 \times 5,00=55,00$ \\
Yüzeysel & $11 \times 1,00=11,00$ & $11 \times 3,00=33,00$ & $11 \times 5,00=55,00$ \\
Derinsel 2 & $7 \times 1,00=7,00$ & $7 \times 3,00=21,00$ & $7 \times 5,00=35,00$ \\
\hline
\end{tabular}

Öğrencilerin alt boyut bazında ortalama puanlarının orta puan değeri olan 33,00 (derinsel 1 ve yüzeysel için) ve 21,00'dan (derinsel 2 için) aşağı ya da yukarı doğru uzaklaşılması öğrenme yaklaşımlarını tercih etme düzeyi olarak değerlendirilmiştir. Başka bir deyişle orta puan değeri, bir öğrenme yaklaşımının orta düzeyde tercih edilmesi anlamında kullanılmış ve ortaya çıkan puanlar bu puan değeri ile karşılaştırılarak değerlendirilmiştir.

Tablo 5'de sunulan ortalama puanlar Tablo 6 ölçüt alınarak incelendiğinde, üç alt ölçek içinde öğrencilerin ortalama puanlarının orta puanın biraz üstünde olduğu görülmektedir. Bu bulgular doğrultusunda, öğrencilerin hem derinsel (derinsel 1 ve 2) hem de yüzeysel öğrenme yaklaşımlarını orta düzeyin biraz üzerinde tercih ettikleri söylenebilir.

Cinsiyet ve Başarı Düzeyinin Lise Öğrencilerinin Fizik Öğrenme Yaklaşımları Üzerindeki Etkileri 
Araştırmanın fizik öğrenme yaklaşımları ile ilgili bağımlı değişkenlerine ait ortalama değerler, cinsiyet ve başarı düzeyi bağımsız değişkenlerine göre iki yönlü MANOVA (twoway MANOVA) analizi ile karşıllaştırılmıştır.

Cinsiyet ve başarı düzeyi değişkenlerine FÖYÖ alt ölçeklerine ait betimsel istatistikler Tablo 7'de verilmiştir.

Tablo 7 Cinsiyet ve Başarı Düzeyi Değişkenlerine Göre FÖYÖ Alt Ölçek Betimsel İstatistikleri

\begin{tabular}{|c|c|c|c|c|c|}
\hline Alt Ölçekler & Cinsiyet & Başarı & $\mathbf{N}$ & $\mathbf{O}$ & SS \\
\hline \multirow{6}{*}{ Derinsel 1} & \multirow{3}{*}{$\mathrm{K}_{1 \mathrm{Z}}$} & Düşük & 42 & 31.43 & 7.94 \\
\hline & & Orta & 81 & 34.52 & 7.60 \\
\hline & & Yüksek & 49 & 35.16 & 6.90 \\
\hline & \multirow{3}{*}{ Erkek } & Düsük & 37 & 32.57 & 8.95 \\
\hline & & Orta & 70 & 35.03 & 7.96 \\
\hline & & Yüksek & 50 & 38.98 & 8.07 \\
\hline \multirow{6}{*}{ Yüzeysel } & \multirow{3}{*}{$\mathrm{K} 1 \mathrm{z}$} & Düşük & 42 & 37.67 & 7.91 \\
\hline & & Orta & 81 & 34.55 & 7.40 \\
\hline & & Yüksek & 49 & 33.69 & 7.99 \\
\hline & \multirow{3}{*}{ Erkek } & Düşük & 37 & 37.49 & 7.28 \\
\hline & & Orta & 70 & 36.24 & 7.47 \\
\hline & & Yüksek & 50 & 31.94 & 8.94 \\
\hline \multirow{6}{*}{ Derinsel 2} & \multirow{3}{*}{$\mathrm{K}_{1 \mathrm{Z}}$} & Düşük & 42 & 23.64 & 5.15 \\
\hline & & Orta & 81 & 25.79 & 4.12 \\
\hline & & Yüksek & 49 & 25.95 & 3.92 \\
\hline & \multirow{3}{*}{ Erkek } & Düşük & 37 & 23.70 & 5.89 \\
\hline & & Orta & 70 & 25.17 & 4.70 \\
\hline & & Yüksek & 50 & 27.52 & 3.58 \\
\hline
\end{tabular}

Öğrencilerin fizik öğrenme yaklaşımlarının cinsiyet ve sınıf düzeylerine göre farklılık gösterip göstermediği iki yönlü MANOVA ile incelenmiş ve sonuçlar Tablo 8'de verilmiştir.

Tablo 8 Cinsiyet ve Fizik Başarı Düzeyine Göre Öğrencilerin Fizik Öğrenme Yaklaşımlarına Ait Manova Analizi Sonuçları

\begin{tabular}{lcccccc}
\hline Etki & $\begin{array}{c}\text { Wilks } \\
\text { Lambda }(\lambda)\end{array}$ & F & $\begin{array}{c}\text { Hipotez } \\
\text { sd }\end{array}$ & $\begin{array}{c}\text { Hata } \\
\text { sd }\end{array}$ & $\mathbf{p}$ & $\boldsymbol{\eta}_{\mathbf{k}}^{2}$ \\
\hline Cinsiyet & 0.982 & 1.944 & 3 & 321 & 0.122 & 0.018 \\
Başarl & 0.924 & 4.327 & 6 & 644 & 0.000 & 0.039 \\
Cinsiyet *Başarl & 0.986 & 0.744 & 6 & 642 & 0.590 & 0.007 \\
\hline
\end{tabular}

MANOVA sonuçları, cinsiyet değişkeninin fizik öğrenme yaklaşımları üzerinde anlamlı etkisinin olmadığını (Wilks' Lambda $=0.982, \mathrm{~F}_{(3,321)}=1.944, \mathrm{p}>0.05, \eta_{\mathrm{k}}{ }^{2}=0.018$ ), başarı düzeyinin anlamlı bir etkiye sahip olduğunu (Wilks' Lambda $=0.924, \mathrm{~F}_{(6,644)}=4.327$, $\mathrm{p}<0.001, \eta_{\mathrm{k}}^{2}=0.039$ ); ancak cinsiyet ve başarı değişkenlerinin etkileşiminin anlamlı etkisinin 
olmadığını (Wilks' Lambda $=0.986, \mathrm{~F}_{(6,642)}=0.744, \mathrm{p}>0.05, \eta_{\mathrm{k}}{ }^{2}=0.007$ ) göstermektedir. Diğer taraftan, bağımsız değişkenlerin etki büyüklügünü belirlemek için kısmi eta kare $\left(\eta_{\mathrm{k}} 2\right)$ değerine bakılmıştır. Elde edilen kısmi eta kare değeri Stevens (1992) tarafından önerildiği şekliyle yorumlanmıştır. Buna göre etki büyüklükleri $\eta_{\mathrm{k}}{ }^{2} \leq 0.01$ için "küçük", $\eta_{\mathrm{k}}{ }^{2}=0.06$ için "orta" ve $\eta_{\mathrm{k}}^{2}=0.14$ için "büyük" olarak gruplanmıştır. Buna göre cinsiyet ve başarı değişkenleri açısından elde edilen kısmi eta kare değerleri (sırasıyla $\eta^{2}=0.018$ ve $\eta^{2}=0.038$ ) göz önünde bulundurulduğunda iki değişkenin de öğrencilerin öğrenme yaklaşımları üzerinde düşük büyüklükte etkiye sahip olduğu görülmektedir.

Gözlenen anlamlı farklılıkların hangi bağımlı değişkenden kaynaklandığı Gruplar Arası Etkileşim Testi tablosundaki (Tablo 9) anlamlılık değerlerine bakılarak yorumlanmış ve karş1laştırmalarda alfa değeri Bonferroni düzeltmesi doğrultusunda $a^{\prime}=0.017(0.05 / 3)$ olarak dikkate alınmıştır.

Tablo 9 Cinsiyet ve Fizik Başarısına Göre Öğrencilerin Fizik Öğrenme Yaklaşımları Alt Ölçek Puanlarının İzleme Analizi Sonuçları

\begin{tabular}{lccccccc}
\hline Kaynak & $\begin{array}{c}\text { Bağımlı } \\
\text { değişken }\end{array}$ & $\begin{array}{c}\text { Kareler } \\
\text { Toplamı }\end{array}$ & Sd & $\begin{array}{c}\text { Ortalamalar } \\
\text { Karesi }\end{array}$ & $\mathbf{F}$ & $\mathbf{p}$ & Kısmi $\eta^{2}$ \\
\hline \multirow{3}{*}{ Cinsiyet } & Derinsel 1 & 253.442 & 1 & 253.442 & 4.104 & 0.044 & 0.013 \\
& Yüzeysel & 0.517 & 1 & 0.517 & 0.008 & 0.927 & 0.000 \\
& Derinsel 2 & 8.517 & 1 & 8.517 & 0.417 & 0.519 & 0.001 \\
\hline \multirow{3}{*}{ Başarl } & Derinsel 1 & 1128.654 & 2 & 564.327 & 9.137 & 0.000 & 0.054 \\
& Yüzeysel & 1011.437 & 2 & 505.719 & 8.296 & 0.000 & 0.049 \\
& Derinsel 2 & 413.116 & 2 & 206.558 & 10.125 & 0.000 & 0.059 \\
\hline \multirow{2}{*}{ Cinsiyet } & Derinsel 1 & 170.107 & 2 & 85.054 & 1.377 & 0.254 & 0.008 \\
Başarl & Yüzeysel & 180.382 & 2 & 90.191 & 1.479 & 0.229 & 0.009 \\
& Derinsel 2 & 71.382 & 2 & 35.691 & 1.750 & 0.175 & 0.011 \\
\hline
\end{tabular}

Bonferroni düzeltmesi dikkate alınarak Tablo 7 incelendiğinde cinsiyete göre, alt

ölçek bazında da öğrencilerin fizik öğrenme yaklaşımları arasında anlamlı farklılıklar olmadığ1 görülmüştür. Fizik başarısına göre, derinsel $1\left(\mathrm{~F}_{(2,323)}=9.137, \mathrm{p}<0.017\right)$, yüzeysel $\left(\mathrm{F}_{(2,323)}=8.296, \mathrm{p}<0.017\right)$ ve derinsel $2 \quad\left(\mathrm{~F}_{(2,323)}=10.125, \mathrm{p}<0.017\right)$ alt boyutlarında öğrencilerin öğrenme yaklaşımları arasında anlamlı farklılıklar vardır. Başarı değişkeni, derinsel 1 alt boyutundaki varyansın \%5.4'ünü, yüzeysel alt boyutundaki varyansın \%4.9'unu ve derinsel 2 alt boyutundaki varyansın \%5.9’unu açıklamıştır. Öğrencilerin öğrenme yaklaşımlarındaki (üç alt boyut için) anlamlı farklılıkların hangi başarı düzeyinden kaynaklandığını belirlemek amacıyla post-hoc çoklu karşılaştırma testlerinden "Bonferonni" ve "Tamhane T2" testi yapılmıştır. Derinsel 1 ve yüzeysel alt boyutlarında varyansların homojenliği varsayımı karşılandığı için Bonferroni testinin sonuçları, derinsel 2 alt boyutunda ise varyansların homojenliği varsayımı karşılanamadığı için Tamhane testi sonuçları dikkate 
alınarak sonuçlar yorumlanmıştır. Çoklu karşılaştırma testlerinin sonuçları Tablo 8'de verilmiştir.

Tablo 10 Başarı Düzeyine Göre Çoklu Karşılaştırma Test Sonuçları

\begin{tabular}{|c|c|c|c|c|c|}
\hline $\begin{array}{l}\text { Bağımlı } \\
\text { değișken }\end{array}$ & Test & (I) Başarı & (J) Başarı & $\begin{array}{l}\text { Ortalama } \\
\text { Farklar(I-J) } \\
\end{array}$ & $\bar{p}$ \\
\hline \multirow{6}{*}{ Derinsel 1} & \multirow{6}{*}{ Bonferroni } & \multirow{2}{*}{ Düşük } & Orta & $-2.7929 *$ & 0.033 \\
\hline & & & Yüksek & $-5.1289 *$ & 0.000 \\
\hline & & \multirow[b]{2}{*}{ Orta } & Düşük & $2.7929 *$ & 0.039 \\
\hline & & & Yüksek & -2.3359 & 0.067 \\
\hline & & \multirow{2}{*}{ Yüksek } & Düşük & $5.1289 *$ & 0.000 \\
\hline & & & Orta & 2.3359 & 0.067 \\
\hline \multirow{6}{*}{ Yüzeysel } & \multirow{6}{*}{ Bonferroni } & \multirow{2}{*}{ Düşük } & Orta & 2.2445 & 0.118 \\
\hline & & & Yüksek & $4.7742 *$ & 0.000 \\
\hline & & \multirow{2}{*}{ Orta } & Düşük & -2.2445 & 0.118 \\
\hline & & & Yüksek & $2.5297^{*}$ & 0.038 \\
\hline & & \multirow{2}{*}{ Yüksek } & Düşük & $-4.7742 *$ & 0.000 \\
\hline & & & Orta & $-2.5297 *$ & 0.038 \\
\hline \multirow{6}{*}{ Derinsel 2} & \multirow{6}{*}{ Tamhane } & \multirow{2}{*}{ Düşük } & Orta & $-1.8324 *$ & 0.033 \\
\hline & & & Yüksek & $-3.0766^{*}$ & 0.000 \\
\hline & & \multirow{2}{*}{ Orta } & Düşük & $1.8324^{*}$ & 0.033 \\
\hline & & & Yüksek & -1.2442 & 0.055 \\
\hline & & \multirow{2}{*}{ Yüksek } & Düşük & $3.0766^{*}$ & 0.000 \\
\hline & & & Orta & 1.2442 & 0.055 \\
\hline
\end{tabular}

Tablo 8 incelendiğinde düşük başarılı öğrencilerin öğrenme yaklaşımları puanları hem derinsel 1 hem de derinsel 2 boyutunda orta ve yüksek başarılı öğrencilerden daha düşüktür. Bu bulgular, düşük başarılı öğrencilerin derinsel yaklaşımı diğer gruptaki öğrencilere kıyasla daha az tercih ettiği anlamına gelmektedir. Yüzeysel yaklaşım boyutunda ise, yüksek başarılı öğrencilerin orta ve düşük başarılı öğrencilere göre öğrenme yaklaşım puanları önemli ölçüde daha düşüktür. $\mathrm{Bu}$ boyuttan düşük puan alınması yüzeysel yaklaşımın yüksek başarılı öğrenciler tarafından daha az tercih edildiği anlamına gelmektedir.

\section{Sonuç ve Tartışma}

Bu çalışmada, Ellez ve Sezgin (2000) tarafından üniversite düzeyine yönelik olarak geliştirilen Öğrenme Yaklaşımları Ölçeği'nin lise düzeyinde fizik dersine uyarlaması (Fizik Öğrenme Yaklaşımları Ölçeği) yapılmıştır. Geçerlik ve güvenirlik çalışması sonuçları, Fizik Öğrenme Yaklaşımları Ölçeği’nin lise düzeyine uygun yapıda geçerli ve güvenilir bir ölçek olduğunu göstermektedir. 
Ayrıca, bu çalışmada Fizik Öğrenme Yaklaşımları Ölçeği kullanılarak lise öğrencilerinin fizik dersini öğrenmeye yönelik yaklaşımlarını tercih etme düzeyleri ve öğrenme yaklaşımlarının cinsiyet ve fizik başarısına göre değişimi incelenmiştir. Araştırmanın sonucunda, öğrencilerin hem derinsel (her iki alt boyutta da) hem de yüzeysel öğrenme yaklaşımlarını orta düzeyin biraz üzerinde tercih ettikleri belirlenmiştir. Derinsel ve yüzeysel öğrenme yaklaşımlarına ait ortalama puanlarının minimum ya da maksimum puanlara yakın olmadığı görülmektedir. Öğrencilerin öğrenme yaklaşımlarına (derinsel ve yüzeysel) ait ortalama puanları incelendiğinde onların belirli bir öğrenme yaklaşımını belirgin düzeyde daha fazla tercih etmediği görülmektedir. Ortaya çıkan bu durum liselerde sunulan öğretimin her iki yaklaşıma da yönlendirici özelliklere sahip olduğunu göstermektedir. Bu bulgu, Ekinci'nin (2009) üniversite (Hacettepe, Mersin ve Süleyman Demirel Üniversiteleri) öğrencileri üzerinde yaptığı araştırmanın bulguları ile paralellik göstermektedir. $\mathrm{Bu}$ araştırmada öğrencilerin yaklaşımlara ilişkin puan ortalamaları hem genel olarak hem de üniversiteler temelinde onları herhangi bir öğrenme yaklaşımı bakımından baskın olarak nitelemeye yetecek kadar yüksek ya da düşük çıkmamıştır. Ekinci bu sonucu, üniversitelerin hem derinlemesine öğrenme hem de yüzeysel öğrenme yaklaşımına yönlendirici özelliklere birlikte sahip olduğu, derinlemesine öğrenmeye yönlendirici özelliklerinin baskın olmadığ1 şeklinde yorumlamıştır.

Ayrıca, araştırmada cinsiyetin ortaöğretim öğrencilerinin fizik öğrenme yaklaşımları üzerinde bir etkisinin bulunmadığı saptanmıştır. Alt boyutlar açısından bakıldığında da istatistiksel açıdan anlamlı bir farklılık yaratmayan cinsiyet değişkeni ortaöğretim düzeyinde kız ve erkek öğrencilerin derinlemesine ve yüzeysel öğrenme yaklaşımlarını benzer bir şekilde kullandıklarını ortaya koymaktadır. Araştırmadan elde edilen bu bulgu cinsiyete göre öğrenme yaklaşımları arasında anlamlı bir farklılığın olmadığı sonucuna ulaşan (Ekinci ve Ekinci, 2007; Öner, 2008; Richardson, 1993; Tural-Dinçer ve Akdeniz, 2008) çalışmalarla paralellik göstermektedir.

Ekinci (2008) yapmış olduğu çalışmada, öğrencilerin öğrenme yaklaşımlarını tercih etme düzeylerini cinsiyete göre ele alan farklı ülkelerde yapılmış çalışmalara bakıldığında, sonuçlarda bir tutarlılık olmadığını rapor etmiştir. Ayrıca alanyazındaki araştırmaların tutarlılık göstermemesinin beklenen bir sonuç olarak karşılanabileceğini çünkü cinsiyete bağlı davranışların kültürel ve sosyo-ekonomik ortamlardan etkilendiğini ve buna bağlı olarak eğitime yükledikleri anlamın farklılaşabileceğini vurgulamıştır. Böyle bir farklılaşmada farklı sonuçlarının ortaya çıkması doğal bir durumdur. 
Araştırmadan elde edilen diğer bir sonuç da düşük başarılı öğrencilerin öğrenme yaklaşımları puanları hem derinsel 1 hem de derinsel 2 boyutunda orta ve yüksek başarılı öğrencilerden daha düşük olduğudur. Yani yüksek ve orta başarılı öğrenciler derinsel yaklaşımı düşük başarılı öğrencilere kıyasla daha çok tercih etmiştir. Yüzeysel yaklaşım boyutunda ise, yüksek başarılı öğrencilerin orta ve düşük başarılı öğrencilere göre öğrenme yaklaşım puanları önemli ölçüde daha düşüktür. Bu boyuttan düşük puan alınması yüzeysel yaklaşımın yüksek başarılı öğrenciler tarafından daha az tercih edildiği anlamına gelmektedir. $\mathrm{Bu}$ bulgu, öğrencilerin fizik not ortalamaları yükseldikçe derinsel öğrenme yaklaşımı puanlarının da artış eğiliminde olduğu şeklinde yorumlanabilir. Bu durum fizik başarısı ile derinsel öğrenme yaklaşımları arasında olumlu bir ilişkinin olduğunu göstermektedir. Lise öğrencilerinde fizik başarısının artması derinsel öğrenme yaklaşımlarını tercih etmelerinden kaynaklanıyor olabilir. Ölçeğin uygulandığı liselerin ilköğretim sonunda sınavla girilen (SBS: Seviye Belirleme Sınavı) bir lise olması ve öğrencilerin giriş puanlarının birbirine yakın olması göz önünde bulundurulursa fizik başarılarındaki farklılığın kaynağı fiziği öğrenmede farklı yaklaşımları tercih etmeleri olabilir. $\mathrm{Bu}$ durum öğrenme öğretme ortamının etkiliği (Ekinci, 2008), öğrencilerin dersle ya da öğretmenle ilgili algılarının farklı olmasından (Richardson, 2005) da etkilenebilir.

Öğrencilerin başarı durumları ve öğrenme yaklaşımları arasında olumlu bir ilişkinin olması sonucu, ilgili alan yazın incelendiğinde de pek çok çalışmayla da desteklenmektedir (Bernardo, 2003; Senemoğlu, Berliner, Yıldız, Doğan, Savaş \& Çelik 2007). Benzer şekilde Ellez ve Sezgin'in (2002) öğretmen adayları ile yaptıkları çalışmanın sonuçları, derinlemesine öğrenme yaklaşımı puanları ile akademik başarı arasında anlamlı bir ilişki olduğunu ortaya koymuştur. Yine, Selçuk, Çalışkan ve Erol'da (2007) araştırmalarında öğretmen adaylarının akademik başarıları ile derinsel öğrenme yaklaşımları arasında anlamlı pozitif ilişki, yüzeysel öğrenme yaklaşımıyla negatif ilişki olduğunu belirtmişlerdir.

\section{Öneriler}

Araştırmanın bulgularından yararlanılarak ileride yapılması planlanan öğrenme yaklaşımları ile ilgili gelecek araştırmalara rehberlik edebilmesi amacıyla lise öğrencilerinin derinsel öğrenme yaklaşımlarının daha baskın olarak ortaya çıkmasına ve eğitim-öğretim sürecinin planlanmasında etkili olabileceği düşünülen bazı öneriler sunulmuştur:

1. İlgili disiplindeki alan yazında çeşitli sınıf düzeylerinde öğrencilerin genel olarak öğrenme yaklaşımlarını araştıran pek çok çalışmaya rastlanmasına rağmen tek bir disiplinde öğrencilerin öğrenme yaklaşımları üzerine, fen öğrenme yaklaşımları vb. 
gibi) yapılan çalışmalar oldukça azdır. Eğer farklı disiplinlerde bu tür araştırmalar yapılacak olunursa öğrencilerin ilgili disiplinde başarısız olma durumları ve öğrencilerin hangi öğrenme yaklaşımını benimsediği ortaya konulabilir.

2. Öğrencilerin fizik dersinde derinsel ve yüzeysel öğrenme yaklaşımlarını tercih etme düzeyleri ve bu tercihlerin (a) dersteki konulara, (b) öğretmenlerin dersi işleme yöntemlerine (c) öğrencinin cinsiyetine ve (d) öğrencinin fizik ders başarısına göre değişimi öğrencilerle yüz yüze yapılacak görüşmeler yoluyla derinlemesine incelenmelidir. Ayrıca, öğretmenler ile yapılacak yüz yüze görüşmeler yoluyla da öğrencilerden elde edilen verilerin kontrolü sağlanabilir.

Güncellenen 2013 Fizik Ortaöğretim Programında öngörüldüğü gibi, öğrencilerin bireysel farklılıkları göz önünde bulundurulmalı, öğrenme ve öğretme sürecine ilişkin planlama yapılırken öğrencilerin sahip olduğu bilgi ve becerilerin neler olduğu kadar, bu bilgilerin öğrenme sürecinde nasıl bir role sahip olabileceği üzerinde de düşünülmeli ve ezberlemek değil, anlamlı öğrenmelerin gerçekleşmesini desteklemek hedeflenmelidir. Bu bağlamda, derinsel öğrenme yaklaşımını desteklemek amacıyla okulda yapılan değerlendirmeler sadece ürünü değil, süreci de içermelidir. Bu sayede öğrenciler sadece not almak için ya da sınıfı geçmek için çalışmayacak süreç içinde anlamlı öğrenmeler gerçekleştirebileceklerdir.

\section{Kaynakça}

Austin, L. B. \& Shore, B. M. (1995). Using concept mapping for assessment in physics. Physics Education, 30(1), 41-45.

Aycan, Ş. \& Yumuşak, A. (2003). Lise müfredatındaki fizik konularının anlaşılma düzeyleri üzerine bir araştırma. Milli Eğitim Dergisi, 159 (Yaz).

Aydoğdu, B. (2009). Fen ve teknoloji dersinde kullantlan farkll deney tekniklerinin ögrencilerin bilimsel süreç becerilerine, bilimin doğasına yönelik görüşlerine, laboratuvara yönelik tutumlarına ve ögrenme yaklaşımlarına etkisi, Doktora Tezi, Dokuz Eylül Üniversitesi Eğitim Bilimleri Enstitüsü. 
Berberoğlu, G. \& Hei, L. M. (2003). A comparison of university students' approaches to learning across Taiwan and Turkey. International Journal of Testing, 3(2), 173-187.

Bernardo. A. B. I. (2003). Approaches to learning and academic achievement of Filipino students. Journal of Genetic Psychology, March, 164, 1.

Bruce, L. B. (2001). Student self-assessment: Encouraging active engagement in learning, Fielding Graduate Institue, unpublished $\mathrm{PhD}$ thesis.

Büyüköztürk, Ş. (2011). Veri Analizi El Kitabı. Ankara: Pegem Akademi.

Byrne, M., Flood, B. \& Willis, P. (2002). The relationship between learning approaches and learning outcomes: a study of irish accounting students. Accounting Education, 11(1), $27-42$.

Byrne, M., Flood, B. \& Willis, P. (1999). Approaches to learning of Irish Students Studying Accounting, DCUBS Research Papers 1997-1998, No.36.

Chin, C. \& Brown, D. E. (2000). Learning in Science: A comparision of deep and surface approaches, Journal of Research in Science Teaching. 37, 2, 109-138.

Çalışkan, S., Selçuk, S,G. \& Erol, M. (2006). Fizik Öğretmen Adaylarının Problem Çözme Davranışlarının Değerlendirilmesi. Hacettepe Üniversitesi Eğitim Fakültesi Dergisi, $30,73-81$.

Dart, B.C., Burnett, P.C. \& Purdie, N.M. (2000). Student's conceptions of learning, the classroom environment, and approaches to learning. The Journal of Educational Research, 93(4), 262-270.

Değermenci, A. (2009). Bă̆lam temelli dokuzuncu sınıf dalgalar ünitesine yönelik materyal geliştirme, uygulama ve değerlendirme. Yüksek Lisans Tezi. Karadeniz Teknik Üniversitesi. Fen Bilimleri Enstitüsü. Trabzon.

Dickie, L. O. (2003). Approach to learning, the cognitive demands of assessment, and achievement in physics. The Canadian Journal of Higher Education, 33(1), 87-111.

Ekinci, E. \& Burgaz, B. (2007). Hacettepe üniversitesi öğrencilerinin bazı akademik hizmetlere ilişkin beklenti ve memnuniyet düzeyleri. Hacettepe Üniversitesi, Ĕ̌itim Fakültesi Dergisi, 33, 120-134.

Ekinci, N. (2008). Üniversite öğrencilerinin öğrenme yaklaşımlarının belirlenmesi ve ögretme-öğrenme süreci değişkenleri ile ilişkileri, Doktora Tezi, Hacettepe Üniversitesi Sosyal Bilimler Enstitüsü. 
Ekinci, N. (2009). Üniversite öğrencilerinin öğrenme yaklaşımları. Eğitim ve Bilim, 34(151), 74-88.

Ellez, M. \& Sezgin, G. (2002). Öğretmen Adaylarının Öğrenme Yaklaşımları. V. Ulusal Fen Bilimleri ve Matematik Eğitimi Kongresi Bildiri Kitapçığı Cilt II, s: 1261-1266.

Entwistle, N.J. \& Ramsden, P. (1983). Understanding student learning. Social Science Researh Council, London: Croom Helm.

Guimberteau, B. (1992). Extracting meaning from physics texts: standards of evaluation used by novices, Paper presented at the Annual Meeting of the American Educational Research Association (San Francisco, CA, April 20-24). (ERIC Document Reproduction Service NO. ED346109).

Harper, K. A., Etkina, E. \& Lin, Y. (2003). Encouraging and analyzing student questions in a large physics course: Meaningful patterns for instructors. Journal of Research in Science Teaching, 40(8), 776-791.

Hua, T.M., Williams, S. \& Hoi, P.S. (2001). Using the Biggs' Process Questionnaire (SPQ) as a diagnostic tool identify "at-risk" students - a Preliminary Study. Retrieved from http://www.learnerstogether.net/storage/Identifying-at-risk-students-with-spq.pdf

Jackson, B. (1994). Assesment practices in art and design: a contribution to student learning? Graham Gibbs (Eds). Improving Student Learning Assessment and Evaluation Oxford: Oxford Centre for Staff Development.

Johnston, J. C. (1994). The role of metacognition in enhancing strategy transfer (Monitoring and Control Instruction). Unpublished $\mathrm{PhD}$ Thesis. University of Washington. Journal of Educational Psychology, 46, 4-11.

Kaplan, R., \& Saccuzzo, D. P. (2005). Psychological testing, principles, applications and issues. 6th edition. Wadsworth Thomson Learning, USA. Chapter 13: 348-349.

Kılıç, D. \& Sağlam, N. (2007). Öğretmen Adaylarının Öğrenme Yaklaşımları. Hacettepe Üniversitesi ve Azerbaycan Devlet Pedagoji Üniversitesi Uluslararası Öğretmen Yetiştirme Politikaları ve Sorunları Sempozyumu. Bakü. 12-14 Mayıs.

Kız1lgüneş, B. (2007). Predictive influence of students' achievement motivation, meaningful learning approach and epistemological beliefs on classification concept achievement. Unpublished Master's Thesis, METU: Ankara. 
Koch, A. \& Eckstein, S. G. (1991). Improvement of reading comprehension of physics texts by students' question formulation. International Journal of Science Education, 13(4), $473-486$.

Koch, A. (2001). Training in metacognition and comprehension of physics texts. Science Education, 85, 758-768.

Marton, F. \& Saljo, R. (1976). On qualitative differences in learning: I - outcome and process, British Journal of Educational Psychology, 46 (2), 115- 127.

Mayya, S.S., Rao, A.K., \& Ramnarayan, K. (2004). Learning approaches, learning difficulties and academic performance of undergraduate students of physiotherapy. The Internet Journal of Allied Health Sciences and Practice, 2(4), 1-6.

M.E.B. Talim ve Terbiye Kurulu Başkanlığı (2013). Ortaöğretim fizik dersi (9, 10, 11 ve 12. Sinıflar) öğretim Programı. http://ttkb.meb.gov.tr/www/guncellenen-ogretimprogramlari/icerik/151.

Nguyen, T.N. (1998). Students' approaches to learning physics in a Vietnamese University. MS Thesis, Simon Fraser University, Canada.

Öner, Y.İ. (2008). Ortaöğretim öğrencilerinin öğrenme yaklaşımlarını etkileyen faktörler (İstanbul örneği). Yayınlanmamış Yüksek Lisans Tezi, Yeditepe Üniversitesi, İstanbul.

Prosser, M \& Millar, R. (1989). The how and what of learning physics. European Journal of Psycholgy in Education, 4, 513-528.

Prosser, M., Walker, P. \& Millar, R. (1996). Differences in students' perceptions of learning. Physics Education, 31, 43-48.

Ramsden, P. (1979). Student learning and perceptions of the academic environment. Higher Education, 8, 411-427.

Ramsden, P. (2000). Learnig to Teaching in Higher Education. London: Newyork Routhladge Falmer.

Ramsden, P. (2003). Learning to teach in higher education, 2nd edn. London and New York: Routledge Farmer.

Ramsden P, Entwistle N (1981). Effects of academic departments on students' approaches to studying. Bri. J. Educ. Psychol., 51(3), 368-383.

Richardson, J. T. E. (2005). Students' perceptions of academic quality and approaches to studying in distance education. British Educational Research Journal, 31, 7-27. 
Richardson, J.T. E. (1993). Gender differences in responses to the approaches to studying inventory. Studies in Higher Education, 18, 3-13.

Richardson, J.T.E. (1994). Using questionnaires to evaluate student learning: Some health warnings, $\quad<$ http://www.lgu.ac.uk/deliberations/oocsd-pubs/1sip-richardson.html $>$ (2002, May25)

Rouet, J. F., Vidal-Abarca, E., Erboul, A. B. \& Millogo, V. (2001). Effects of information search tasks on the comprehension of instructional text. Discourse Processes, 31(2), $163-186$.

Senemoglu, N. Berliner, D. Yıldız, G., Dogan, E., Savas, B. \& Çelik, K. (2007). Approaches to learning and study skills of Turkish and American students in colleges of education. Uluslararası Öğretmen Yetiştirme Politikaları ve Sorunları Sempozyumu. Bakü. (547551)

Sezgin Selçuk, G, Çalışkan, S., \& Erol, M. (2007). Evaluation of learning approaches for prospective physics teachers. GÜ, Gazi Eğitim Fakültesi Dergisi, 27(2), 25-41.

Sezgin Selçuk, G., Sahin, M. \& Açıköz, K. (2011). The effects of learning strategy instruction on achievement, attitude, and achievement motivation in a physics course. Research in Science Education, 41(1), 39-62.

Stevens, J. (1992). Applied multivariate statisics for the social sciences. Lawrance Erlbaum Assosiates (Hillsdale, NJ).

Trigwell, K., Prosser, M. \& Waterhouse, F. (1999). Relations between teachers' approaches to teaching and students' approaches to Learning. Higher Education, 37(1), 57-70.

Tural-Dinçer, G. \& Akdeniz, A.R. (2008). Examining learning approaches of science student teachers according to the class level and gender. US-China Education Review, 5(12), 54-59.

Ünal-Çoban, G. \& Ergin, Ö. (2006). Buluş yoluyla fen öğretiminin öğrencilerin akademik başarılarına, öğrenme yaklaşımlarına ve tutumlarına etkisi, Türk Fen Eğitimi Dergisi, $3(1), 36-52$.

Vertenten, K. (2002). Learning to learn physics: The implementation of process oriented instruction in the first year of higher education. Unpublished $\mathrm{PhD}$ Thesis. Universitaire Instelling Antwerpen.

Weinstein, C. E. \& Mayer, R. E. (1986). The teaching of learning strategies. In M. Wittrock, ed. Handbook of research on teaching, pp. 315-327. New York: Macmillan. 
Yıldız, E. (2008). 5E modelinin kullanıldı̆̆ı kavramsal değişime dayalı öğretimde üst biliş̧in etkileri: 7. sinıf kuvvet ve hareket ünitesine yönelik bir uygulama. Yayınlanmamış Doktora Tezi, Eğitim Bilimleri Enstitüsü, Dokuz Eylül Üniversitesi: İzmir.

Yiğit, N., Devecioğlu, Y. \& Ayvacı, H. Ş. (2002). İlköğretim fen Bilgisi öğrencilerinin fen kavramlarını günlük yaşamdaki olgu ve olaylarla ilişkilendirme düzeyleri. V. Ulusal Fen Bilimler ve Matematik Eğitimi Kongresi, ODTÜ. Ankara.

Zieneddine, A. \& Abd-El-Khalick, F. (2001). Doing the right thing versus doing the right thing right: Concept mapping in a freshmen physics laboratory. European Journal of Physics, 22, 501-511. 